Canadian University Music Review

Revue de musique des universités canadiennes

\title{
Postmodern Interpretations of Satie's Parade
}

\section{Daniel Albright}

Volume 22, numéro 1, 2001

Jean Cocteau: Evangelist of the Avant-garde

Jean Cocteau : évangéliste de l'avant-garde

URI : https://id.erudit.org/iderudit/1014497ar

DOI : https://doi.org/10.7202/1014497ar

Aller au sommaire du numéro

Éditeur(s)

Canadian University Music Society / Société de musique des universités canadiennes

ISSN

0710-0353 (imprimé)

2291-2436 (numérique)

Découvrir la revue

Citer cet article

Albright, D. (2001). Postmodern Interpretations of Satie's Parade. Canadian University Music Review / Revue de musique des universités canadiennes, 22(1), 22-39. https://doi.org/10.7202/1014497ar
Résumé de l'article

Si le postmodernisme peut se concevoir de façon a-historique comme une catégorie stylistique clé, quel que soit le moment ou le lieu, beaucoup d'œuvres plus anciennes prennent tout à coup, à l'époque actuelle, une certaine importance. Cet essai illustre ce point de vue en qualifiant Erik Satie de postmoderniste. En effet, sa musique est marquée par le bricolage (le mouvement « Edriophthalma » des Embryons desséchés de 1913 emprunte, selon la partition, un thème tiré « d'une célèbre mazurka de Schubert »), par la multiplicité des styles (les chansons de cabaret écrites pour Vincent Hyspa, ou encore Parade et ses citations d'Irving Berlin) et par le matérialisme du signifiant (ce que Satie nomme la musique d'ameublement).
All Rights Reserved (C Canadian University Music Society / Société de musique des universités canadiennes, 2002
Ce document est protégé par la loi sur le droit d'auteur. L'utilisation des services d'Érudit (y compris la reproduction) est assujettie à sa politique d'utilisation que vous pouvez consulter en ligne.

https://apropos.erudit.org/fr/usagers/politique-dutilisation/ 


\title{
POSTMODERN INTERPRETATIONS OF SATIE'S PARADE
}

\author{
Daniel Albright
}

\section{EARLY POSTMODERNISM}

The Irish poet William Butler Yeats (1865-1939) thought that some artists led bizarre and unhappy lives because their personalities were so far out of phase with their historical eras that they were forced to wear a false mask - that is, to live as caricatures of themselves. For example, Yeats considered that he was a Romantic poet born too late: a histrionic and effortful presence, an object of mockery to the Modern age. ${ }^{1}$ Yeats indeed seemed to his contemporaries a spooky, ethereal sort of man, so superstitious that he once cut a square out of his fur coat for fear of disturbing a sleeping cat. The Romantic poet, to Yeats, lived in a subjective phantasmagoria, a delirium of private images; while Yeats regarded the twentieth century as an age devoted to the death of imagination, an age which tried to cure itself of desire by hewing to the stolid surfaces of things-as-they-are.

The French composer Erik Satie (1866-1925) was an almost exact contemporary of Yeats, and illustrates Yeats's predicament from the opposite direction. Satie too seems out of phase with his historical era-a connoisseur of paradoxes and parapluies, threadbare dandy, high aesthete of low-brow art, irritable and imperturbable, the snowman of lyric. But it seems retrospectively that this phase-shift arose, not from Satie's adherence to an outworn aesthetic, but from his remarkable anticipation of the aesthetic of the late twentieth century, what we call nowadays postmodernism. Yeats was right in believing that the age was moving toward a rejection of high metaphor, a rejection of transcendence, even a rejection of imagination. Among the artists of the early twentieth century, no one was more expert in rejection than Satie: his whole career is a gran rifiuto of all that is grand. Satie cast a cold eye on impressionism, on expressionism, on most of the vibrant movements of the age. If there is a certain aggressive quality to his reticence, that can be explained by the fact that he lived in the age of the Panama Canal and the novels of Proust, an age characterized by large projects and orotund manifestos, an age in which reticence seemed, if not a vice, at least one of the lesser virtues.

A list of some of the attributes of postmodernism shows just how easily Satie fits the category.

1 See William Butler Yeats, $A$ Critical Edition of Yeats's A Vision (1925), ed. George Mills Harper and Walter K. Hood (London: Macmillan, 1978), especially Book I. 


\section{Bricolage}

The jury-rigging of art, the assembling of the art object from the odds and ends of older art, in a denatured and desecrated fashion, in order to expose the purely arbitrary character of the signs that all artists, past and present, employ. In this sense the modality of postmodernist art is ironic quotation-or a kind of quotedness so thoroughgoing that it disables irony by providing no stable meaning to be ironic against. Art history is wholly flattened, denarratized: the passage of centuries shows no progress, development, or flowering of art, only a steady accumulation of shiny familiar junk, such as the plagal cadence, the first four notes of Beethoven's Fifth Symphony, or the Tristan chord.

Satie is one of the first completely equipped bricoleurs. For example, the Edriophthalma movement from Satie's Embryons desséchés (1913) borrows a theme, according to the score, "from a celebrated mazurka by Schubert"actually the second theme of the funeral march in Chopin's second sonata; similarly, the first theme of Chopin's funeral march appears in the Entr'acte cinématographique from Relâche (1924). When Satie quotes, he usually flattens the salience of the quoted material, renders the material dysfunctional: Chopin's first theme is so hamstrung by Satie's consolidation of the last two quarter-notes of each bar into a half-note that its solemn tread dwindles into an amusing amble; the mighty march becomes a near-blank sign-board figured with the word "funeral" in thin sans-serif lettering. Chopin's second theme is literally flattened, since Satie reduces its melodic compass; the theme can not recall itself properly, as if it were infected with a sort of melodic amnesia: am I a Schubert mazurka? or something else? Throughout the Embryons desséchés, athematic gestures (scurrying frills, ludicrously prolonged cadences) seem to be the formaldehyde in which gross quotations are pickled. Antiseptically murdered tunes, ranged on shelves-what could be more postmodern? Irony is a means for multiplying meaning; Satie's disabled irony instead is a subtraction of meaning.

\section{Polystylism}

This is bricolage on the level of technique instead of content. The polystylist may combine Gregorian chant, three-chord pop tunes, and obnoxious dissonances into a single composition, in order to create incongruities that deny the propriety or the tenability of any single style.

Satie was one of the first composers influenced by Scott Joplin and John Philip Sousa: as early as 1904 he wrote an intermezzo américain, La Diva de l'Empire, with mild ragtime syncopation; by then he was an experienced cabaret artist, having written songs with the comedian Vincent Hyspa since 1899. Satie made little fuss about the distinction between the highbrow and lowbrow; as we will see, Parade strangely blends the ragtime and the highfalutin, advanced musical technique and mere noise.

Satie's play Le Piège de Méduse (1913) turns polystylism into a technique for spoken drama. The plot concerns a dutiful young man, Astolpho, who asks Baron Medusa for the hand of his daughter Frisette - the most conventional of possible plots, complicated by the fact that the characters are almost wholly 
unable to talk to one another. Astolpho speaks the formal language of etiquette manuals; Medusa's servant Polycarpe speaks the insolent language of tradeunion politics; while Medusa himself speaks Satie, a vividly defective Francolunar tongue:

Medusa. Does he love me, this young man? ... I must know. Without knowing I will not be able to sleep easily, or to drink my fill. I will become the shadow of myself. I am going to lay a trap for him, an obvious trap.... I want to have a son-in-law who is really mine, who sees only through my mouth, who takes pleasure in filling himself with my words, who confounds himself [se confond] with me; I would not like to have an egoist for a son-in-law, that would be too bad ...

Listen! The moment has come to lay my trap.... Young man, come near.... Tell me ... Do you know how to dance on an eye ... on a left eye?

Astolpho. (choking with surprise) ... ? ... No.

Medusa. Good! He is frank! (His face expresses the greatest ravishment.)

Be aware, my son-in-law, that you are entering an illustrious house, the house of Medusa. My family is an old family, which has given its name to an invertebrate animal of the class of cephales [céphales], a very beautiful class! This animal lives in the sea. ${ }^{2}$

Méduse, of course, is French for jellyfish. The jellyfish snares its prey in its tentacles and slowly assimilates it through a kind of external digestion. Baron Medusa hopes to do the same thing, to achieve such an assimilation of his prospective son-in-law that Astolpho will be able to see only through Medusa's mouth, will so fully confuse himself with Medusa that he will not know where he begins and Medusa ends. Stray sense-organs keep popping up in the wrong place: a left eye becomes a good surface on which to dance. Medusa seems to hope (and this is the great patriarchal hope) that the family will turn into an undifferentiated blob cooperant to the father's best interests. Satie himself is a medusa not of sons-in-law but of styles; in Satie's work the chorale, the fugue, the Chopin march, are sucked smooth into neutral acoustic material.

\section{Materialism of signifiers}

One hallmark of postmodernism is the arraying of signifiers that assert their opacity, that refuse to signify anything in particular. In paintings such as Jasper Johns's, an American flag is reduced to decoration, a figure 3 into a squiggle, a plus-sign into a pattern-unit. Satie is the great materialist of music: his whole program for musique d'ameublement is a method for demoting pre-existing sounds into inaudible mental objects, what John Cage would later call silence. As Satie said,

You know, there's a need to create furniture music, that is to say, music that would be a part of the surrounding noises and that would take them into

2Erik Satie, Le Piège de Méduse (Paris: Salabert, 1954). All translations are the author's, unless otherwise noted. 
account. I see it as melodious, as masking the clatter of knives and forks without drowning it out completely, without imposing itself. It would fill up the awkward silences ... it would neutralize the street noises ... ${ }^{3}$

Alas, Satie's only public performance of furniture music-endlessly repeated commonplace figures from Saint-Saëns's Danse Macabre and Thomas's Mignon, played by a small band at the intermission of a play-turned out to be a fiasco when those within earshot insisted on listening to it instead of proceeding about their normal business, even though Satie kept shouting, "Don't listen!" Satie's audience expected semantically dense, emotionally quickening music, a music that heightened the vivacity of the listeners' responses to the world; but Satie intended to produce music that receded into the background, an unobtrusive continuo to daily action. Here music precipitates, reifies, until it has the same thingly status as a creaky old ruin of a rocking chair, a familiar assist to private musing.

One of the finest passages from Satie's Mémoires d'un amnésique concerns the materialism of music:

Everyone will tell you that I am not a musician. It's true.

Since the beginning of my career, I have classified myself among the phonometrographers. My labors are pure phonometrics.... It is scientific thought that dominates.

Besides, I have more pleasure in measuring a sound than in hearing it. Phonometer in hand, I labor joyously and confidently....

The first time I provided myself with a phonoscope, I examined a B-flat of middle size. I assure you, I have never seen anything more repugnant. I called my servant to make him see it.

With the phono-weigher [phono-peseur], a very common, ordinary Fsharp attained 93 kilograms. It emanated from a fat tenor whose weight I took....

In order to write my Pièces froides, I availed myself of a kaleidophonerecorder. That took seven minutes. I called my servant to make him hear them.

I can well say that phonology is superior to music. It's more varied. The pecuniary reward is greater. I owe my fortune to it.

In any case, with a motodynamophone, a phonometrician with mediocre training can easily notate more sounds than the most skilled musician can, in the same amount of time, with the same effort. It is thanks to that machine that I've written so much.

The future lies with philophony. ${ }^{4}$

Satie does not go as far as John Cage, who was such a perfect materialist of sound that he insisted on hearing any audible event that came by as a thing in itself. For Cage, each separate note was an end, not a means-not one-third of a triad, or a leading-tone, or any other sort of kinetic and progressive entity.

3 In Alan M. Gillmor, Erik Satie (New York: W. W. Norton \& Company, 1988), 232, citing Fernand Léger, "Satie inconnu," La Revue musicale 214 (1952): 137.

4In Rollo H. Myers, Erik Satie (New York: Dover Publications, Inc., 1968), 142. 
But one reason for Cage's reverence toward Satie was that Satie's aesthetic was of such materialist character. In early works such as the Gnossiennes, or late works such as the Entr'acte cinématographique, a pattern-unit (a chord, a bar, a phrase) will keep alternating with another pattern-unit, in a deliberately non-progressive manner; often one is just as effectively tonic, or dominant, as the other. Satie's preposterously nuanced directions to the performer (Etre visible un moment or Un peut cuit-from Pièces froides) only emphasize that any nuance would be equally relevant, equally irrelevant, to these solidly crafted phonic artifacts. Sitting heavily in their matrix of fantasy-their weird titles, their queasily chummy or offputtingly indifferent attitude toward musical tradition-Satie's pieces clench themselves, defy penetration. They don't easily dance, they don't easily sing, they resist any sort of Romantic appassionato; they are objects made of sound, occupying space, waiting patiently for the phonometrician to perform calculations.

They especially protest at any attempt to fasten any sort of significance to their signifiers; as signs, they remain obstinately defective. What does, say, Edriophthalma mean? How should one feel upon hearing it? In fact, every attempt to align to it a meaning, an emotional quality, is likely to fail: it is a kind of pianistic machine for draining Chopin's funeral march of any sense of the funereal. But after eviscerating Chopin, the piece seems to propose no alternative to occupy the deleted semantic space. It is an un-funeral march. Satie is properly called a precursor to the Surrealists precisely because he was extremely fond of wrong meanings-since wrong meanings are a useful technique for gesturing at an absence of meaning. Consider, for example, his early "Christian ballet" Uspud (1892). Here is J. P. Contamine's scenario to Act I-Satie carefully inscribed each of these phrases over the relevant (or "relevant") passage in his score:

Act I

a deserted beach; in the middle a statue; in the distance the sea.

USPUD in persian dress.

uspud returns from the torture of the christians and brings back relics. he heaps them at the foot of the statue and burns them; the smoke turns into seraphs who vanish into air.

a formidable clap of thunder resounds; the statue falls into pieces. uspud is dismayed.

suddenly the sky grows white again. a very beautiful woman, clad in a gold tunic, and whose breast is pierced by a dagger, appears before uspud and stretches her arms to him. it is the christian church.

uspud, astonished, takes sand and rubs his eyes.

fanfare of trumpets. aerial procession of martyrs who curse uspud.

uspud gathers stones and throws them at the christian church. the stones turn into balls of fire. uspud's fury. he picks up a very large stone which explodes with a noise; flames surge up and from their midst stars fly out. great convulsion of nature. ${ }^{5}$ 
Most of the music that accompanies these apocalyptic ferocities is marked très lent and piano. The aerial martyrs curse Uspud to a slow tune for harps playing in octaves; soft monotone harps recur for the grande convulsion de la nature at the end of the act. This is a flagrant offense against all the semantic systems of music: Satie is disabling our schemes for interpreting musical gesture by providing tranquil evocations of heaven, when the spectacle is a fireworks for the end of the world. In Satie's ballets, in his film score, the music does what it can to retain its uneventfulness, its irrelevance, its disengagement from the images that are synchronized with it.

\section{LOOPS}

When Satie wrote Uspud in 1892, he was a little-known composer working on a spectacle for an obscure bunch of fanatics; when Satie wrote Parade in 1917, he was a well-known composer working with Picasso, Cocteau, and the most gifted impresario in the history of Europe, Serge Diaghilev. Much of the internal tension of Parade comes from the collision of Picasso's integrating, allegorical, sexualizing, essentially Modernist intelligence with Satie's disintegrating, semantically erosive, apathetic, proto-postmodernist intelligence. Cocteau was able to follow both lines of approach: Cocteau's scenario provided an allegory of the terror and histrionic pathos of circus performers, in a manner well aligned with Picasso's early paintings of acrobats and clowns; but (as we shall see) Cocteau's theory of ballet réaliste, formulated from his experience with the whole of Parade, is quite Satie-esque, in that it treasures signifiers and not signifieds. For Cocteau prized the choreographic shock of street gestures liberated from the context of the street, liberated from the burden of meaning.

From the beginning, Cocteau revealed himself as Satie's ideal collaborator, by devising a scenario for a ballet in which nothing happens. In Uspud, Satie had to find ways of anesthetizing an over-eventful scenario; but Parade came to him in a pre-dysfunctionalized state, as a series of loops, 360 degree turns that leave the spectacle in the same condition in which it began. This is the ballet's scenario:

At Country Fairs it is usual for a dancer or acrobat to give a performance in front of the booth in order to attract people to the turnstiles. The same idea, brought up-to-date and treated with accentuated realism, underlies the Ballet "Parade."

The scene represents a Sunday Fair in Paris. There is a travelling Theatre, and three Music Hall turns are employed as Parade. There are the Chinese Conjuror, an American Girl, and a pair of Acrobats.

Three Managers are occupied in advertising the show. They tell each other that the crowd in front is confusing the outside performance with the show which is about to take place within, and they try, in the crudest fashion, to induce the public to come and see the entertainment within, but the crowd remains unconvinced. After the last performance the Managers make another effort, but the Theatre remains empty. The Chinaman, the Acrobats, and the American Girl, seeing that the Mana- 
gers have failed, make a last appeal on their own account. But it is too late. $^{6}$

One of the meanings of the French word parade is a kind of ante-theatre to a carnival show: a sample of the merchandise designed to lure paying customers. The ballet Parade is constructed entirely around rhythms of advertising-and, as a sometime copy-writer, James Joyce, noted in Ulysses, "for an advertisement you must have repetition. That's the whole secret." 7 Parade is a parade in vain: the lack of success drives the performers to increasingly frenzied repetitions in order to attract the onlookers, but no one will bite. The ballet is a series of instant replays of itself.

Furthermore, there is a strongly circular quality to the individual turns. Léonide Massine-who wore Picasso's pretty costume while pantomiming the Chinese Conjuror-left this account of his act:

Cocteau ... suggested that I should go through the motions of swallowing an egg. The idea appealed to me. With an elaborate flourish I pretended to produce an egg from my sleeve and put it in my mouth. When I had mimed the action of swallowing it, I stretched out my arms, slid my left leg sidewards till I was almost sitting down, and with my left hand pretended to pull the egg from the toe of my shoe. ${ }^{8}$

The egg's journey is a remarkable one, but it ends where it began-the trick is as round as the egg itself. This is, of course, typical of magician's tricks: they depend on the reversibility of irreversible things, such as the digestion of food, or the cutting-up of paper into thousands of pieces, or the sawing-in-half of a lady. Such a trick is less an event than a parody of an event: a complicated demonstration that nothing whatever has happened. The egg-trick is a kind of whorl in time, a non-progressive action. And Parade as a whole is nothing but a sum of such zeroes.

What sort of music should accompany this sort of laborious non-action? One good possibility would be furniture music, since its asemiosis would beautifully match the inconsequence on stage. In 1917-the year of Parade-Cocteau quoted with glee Satie's squib against Wagner: "Look, a property tree doesn't go into convulsions when a character enters the stage." Behind that remark lies a whole philosophy of music theatre: the music ought to be a rigid, immiscible background for the stage action, simply a sonorous equivalent to the cut-out trees and two-dimensional houses. Theatre music should exercise discretion and tact, like any good piece of furniture.

6In Francis Steegmuller, Cocteau, A Biography (Boston: D. R. Godine, 1986), 161, trans. Steegmuller, citing a program from His Majesty's Theatre, London, 15 July 1926.

7 James Joyce, Ulysses: A Critical and Synoptic Edition, ed. Hans Walter Gabler et al. (New York: Garland Publishing, 1986), Episode 12, 11, 1147-48.

8In Deborah Menaker Rothschild, Picasso's "Parade": From Street to Stage (London: Sotheby's Publications, 1991), 91. This is an indispensable book for the student of Parade.

9In Jean Cocteau, Le Coq et l'Arlequin: notes autour de la musique (Paris: Éditions de la Sirène, 1918), 28. 
And yet, the music of Parade is not exactly musique d'ameublement; it is memorable, even disturbing. All traditional music, perhaps all traditional art, consists of the binding-together of variable elements by fixed elements-or, to put it another way, the disruption of fixed elements by variable elements. A chaconne, for example, has a fixed ground bass supporting irregular flights in the treble; and most any piece of tonal music can be analyzed in terms of a rigid template and unpredictable choices. But in Parade the fixed elements are so profoundly fixed, as if pounded in with a pile-driver, that it's impossible for the variable elements to make them budge, no matter how frenzied they become. The musical fascination derives from the conflict between the immobile and the irresistible: whirling centrifugal figures keep struggling in vain to dislodge a motionless center.

The first turn-the Chinese Conjuror-offers a clear demonstration. The fixed elements here are scale degrees 7-2-3-that is, B-D-E in C major, a pentatonic sound suitable for China. This is the striking motive played by trumpet and trombone. But this stiff three-note pattern governs the music long before the brass motive appears: the opening bars of Prestidigitateur chinois, and much of the subsequent music, consist of an unsettled repetitious scamper of scale degrees 1-4-3-7, 4-3-2, 4-3-3, 4-3-7, and so forth, in which all the 4-3 figures are sixteenth notes and the other notes are eighth notes. If all the brief 4-3 figures are deleted, the scamper reduces to 1-7-2-3; it is simply a disguised version of the basic 7-2-3 motive of this scene. The scamper keeps shifting its instrumentation and shifting its meter (between $3 / 8$ and 2/4); but these tuggings, recolorings, and dislocations do little to hide the essential monotony of the scamper-one of the main pattern-units of the piece.

The scamper, despite its slight eccentricities, is a music loop, exactly comparable to such action loops as the Conjuror's swallowing the egg and pulling it from the toe of his shoe; and the insistent 7-2-3 brass figure is simply a balder presentation of the same loop. It could be argued that Satie has devised a musical strategy for imitating the action-that the music is an active participant in the circularity of the conjuring, rather than an inert backdrop to it. But I find it hard to imagine a performance of Parade in which the music would seem to reinforce the events, to mark them more deeply in the listener's mind. The music loop inhabits its self-engrossed domain of sound, and the conjuring loop inhabits its self-engrossed domain of action; their forms are congruent, but they occupy separate theatrical spaces. Neither the music nor the action is going anywhere; they resemble one another in the way that an absence of apples resembles an absence of oranges.

In addition to the plane of music and the plane of action, there is a third, wholly imaginary plane, the plane of the spoken text that Cocteau prepared and never heard performed. If the author had not been disappointed, the spectator would have heard Satie's music, watched Massine's pantomime, while a carnival barker was saying:

$$
\begin{aligned}
& \text { A-WELL-INFORMED-MAN-IS-WORTH-TWO! } \\
& \text { IF-you-want-to-become-rich. } \\
& \text { IF-you-feel-sick-IF-you-feel-tired }
\end{aligned}
$$




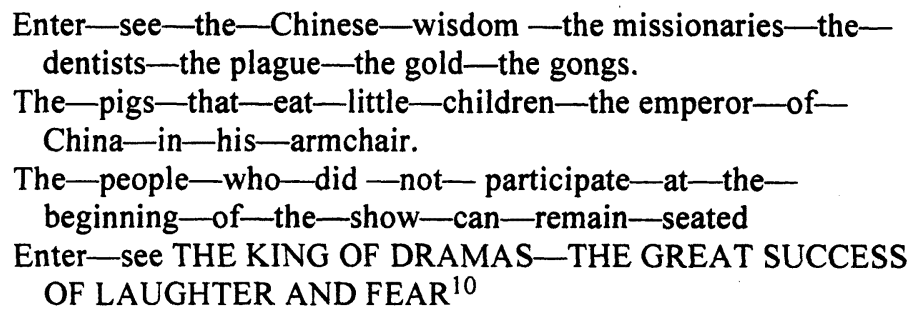

In other words, "You ain't seen nothin' yet." The parade, the theatre in front of the real theatre, dismisses its own entertainment value; in the unseen (and non-existent) inner theatre lie unimaginable wonders and terrors. The empty loops of music and conjuring are signs of the emptiness of a liminal realm of advertising, a no man's land between common life (where you're sick, you're tired, and you'd like more money) and the monstrous exhilarations of the freak show within.

Furthermore, Cocteau hoped that certain muffled sounds from the occult invisible theatre would penetrate the parade and tease the audience. In Satie's autograph of the score, at a point where clarinets enter (corresponding to five bars after rehearsal number [15] in the published score), some Paroles supprimées are written: Ils lui crevèrent les yeux, lui arrachèrent la langue ("they gouge out his eyes, tear out his tongue"); ${ }^{11}$ and then, after the double bar, above some particularly mild, unthreatening, and monotonous music-true furniture music-Satie wrote bruit, the howl of the tortured missionary. This section is accompanied by an unusual musical instrument, a spinning lottery wheel; and perhaps all the loops in Parade are in some sense versions of the Wheel of Fortune, inscribing its arbitrary circles in human space. O fortuna, velut luna, statu variabilis!

Parade is, then, a buffer between the audience and an expressionist spectacle. Perhaps Cocteau heard in his inner ear, when he thought of missionaries tortured by the Chinese, something like the torture scene in Puccini's Tosca (1900), where Cavaradossi's offstage screams punctuate the extremely tense music. Cocteau (who often enjoyed comparing the scandalous premiere of Parade to that of The Rite of Spring four years earlier) may also have conceived Parade as a kind of deconstruction of a Stravinsky ballet:

For most artists, a work wouldn't know how to be beautiful without an intrigue of mysticism, of love, or of annoyance. The short, the gay, the sad without any idyllic quality, are suspect. The hypocritical elegance of the Chinese Conjuror, the melancholy of the Little Girl's steamboats, the touching silliness of the Acrobats, everything that has remained a dead letter for Parade's audience, would have pleased it if the Acrobat had loved the little girl and had been killed by the jealous Conjuror, killed in turn by the Acrobat's wife, or any of thirty-six other dramatic combinations. ${ }^{12}$

10In Rothschild, Picasso's "Parade", 77.

11 Ibid., 92.

12Cocteau, Le Coq et l'Arlequin, 41-42. 
Lurking behind Parade is an undramatized drama along the lines of I Pagliacci-or of Petrushka (1911), which, like Parade, has a conjuror, an Oriental entertainer (in this case a Moor), and several other carnival performers. In Petrushka the characters are caught up in a conventional melodrama of amorous intrigue, jealousy, and murder; but in Parade the performers inhabit separate performing spaces, like window-displays in a department store. Cocteau thought of Satie's score as

a masterpiece of architecture; that's what ears accustomed to vagueness and thrills can't understand.... The numerous motifs, each distinct from the others, like objects, follow one another without development and don't get tangled together [ne s'enchevêtrent pas].... Never any sortileges, reprises, sleazy caresses, fevers, miasmas. Never does Satie "stir up the swamp."13

But Cocteau also was an architect, displaying distinct theatrical objects in carefully immured areas: it is not far from the dramatic method of Parade to the dramatic method that Stravinsky and Cocteau toyed with (but discarded) for Oedipus Rex (1927): let each character occupy an individual mini-stage, and draw back his or her private curtain before starting to sing. ${ }^{14}$ Just as Satie pulled apart the constituents of his music into pattern-units that take no notice of one another, so Cocteau pulled apart the constituents of his scenario into a series of black-out sketches-the circus equivalent of soliloquy, soliloquy, duet.

But today we may hear other things in the unheard theatre behind Parade, beyond Tosca or Petrushka or anything else that Parade's creators might have known. In 1917, Schoenberg's Erwartung was already eight years old, though it would have to wait seven more years until its first performance. Erwartung is a long musical scream-perhaps not quite the same sort of scream that a missionary tortured by the Chinese would have screamed, but, on the other hand, how much does one scream differ from another? When Satie ridiculed Wagner for making the property trees go into convulsions, he was ridiculing the "atonal" Schoenberg without having heard him, for Erwartung is a continuous convulsion of music in sympathy with the character's psychic torment. In the whole context of the twentieth century, Parade looks like a kind of machine for neutralizing Erwartung, for demoting its expressive extremities to suppressed backstage cries: Satie found music that regards torture with urbane aplomb. Erwartung aspires to catharsis, to exhaustion through emotional saturation; but Parade is pre-catharized, evacuated of troubling material before it begins. Erwartung is willing to contemplate any combination of notes, any sequence of chords; Parade is a stringently self-limiting domain, in which

13Ibid., 40.

14 See Igor Stravinsky and Robert Craft, Dialogues (Berkeley: University of California Press, 1982), 23. One is reminded here directly of Petrushka where the drama remains undramatized precisely until the moment that the conjurer draws back the curtain and brings the puppets to life. Prior to the three flute toots they are but "window-displays in a fair tent"; in a way conventional melodrama is overlaid on them as well. 
smooth impenetrable sound-hunks disengage themselves from all need to evolve or to fit into models of cognitive or perceptual activity. It is a theatre-city walled up against unwanted feelings, so completely sealed that the missionary's shrieks were deleted from the text before the first performance. Perhaps Parade is what Erwartung sounds like with its tongue torn out: a sort of gesturing-mute, but not silent-at zones of human experience that defy expression. In 1917 the noises of war were never far from the ears of Paris, and Parade's method of dealing with terror through cultivated apathy makes it one of the profoundest artistic response to the Great War.

The Saran-wrapped surfaces of late-twentieth-century postmodernism, surfaces that both expose and evade, may also be a response, in part, to matters that the artist would rather ignore. The fun of non-referentiality is always heightened by the presence of things best not referred to. Indeed ostentatious absence of meaning tends to be read as a form of gesticulation at the taboo, which usually rushes in to fill vacuums of signification. In a sense, postmodernism, for all its lazy desecrations, has brought into being an entire taboo universe.

\section{Cubes}

Parade is a profound response not only to the Great War, but also to avantgarde art, from within avant-garde art: an act of self-scrutiny by its creators, an attempt to find the meaning of their previous work. As Jeffrey Weiss has shown, ${ }^{15}$ Picasso had, by 1917 , seen the cubist painter-sometimes dressed in a costume made up of cubes-become a figure of fun on the popular stage, in fashion shows, and so forth; and cubist drawing-methods become a stock element of cartoons and even advertising. Parade is an attempt to create a totally cubist reality - as if the universe had been swallowed up by a simulacrum of itself, in the manner of Borges's imaginary country where a 1:1 scale map was unfurled over the entire area. ${ }^{16}$ This cubist land of feigning can be understood as a displacement of pain, a reconstruction of life rendered hard, safe, and witty by art. Indeed Parade is far too safe-the sharp edges of the cubes no longer have any cutting force. In some ways it is remarkable that Picasso would cooperate in constructing such a monstrous expansion and neutering of cubism, the Peewee's Playhouse version of high art. But Picasso too could enjoy weightlessness and frivolity.

The evolution of the Managers during the development of Parade was the most conspicuous cubifying of the spectacle. What became Parade started as a piece called David, ${ }^{17}$ for which Cocteau tried to coax Stravinsky into writing music: the parade was to be a come-on to a Biblical story, and a clown hidden

15See Jeffrey Weiss, The Popular Culture of Modern Art: Picasso, Duchamp, and Avant-Gardism (New Haven: Yale University Press, 1994).

16See Jorge Luis Borges, Dreamtigers [El Hacedor], trans. Mildred Boyer and Harold Morland (New York: E. P. Dutton, Inc., 1970), 90.

17See Steegmuller, Cocteau, A Biography, 94. See Tom Gordon's discussion of David on pp. 12-20 of this issue. 
in a box would, through a loudspeaker, urge the public to enter the booth. Cocteau at first hoped that Parade would have a similar premise:

In the first version the Managers didn't exist. After each Music-Hall number, an anonymous voice, coming through an amplifying box (a theatrical imitation of the fair-ground gramophone, an antique mask in the modern fashion), sang out a type-phrase, summing up the perspectives of the character, opening a breach on the dream. ${ }^{18}$

But in the finished Parade, the masque antique à la mode moderne was no longer a hidden surface for projecting a loud voice, but a silent and extremely conspicuous thing; indeed it is the strongest evidence of Cocteau's demotion in favor of Picasso, of the demotion of text in favor of visual spectacle. (I know of no other collaboration in the history of art in which the component artistic media seem so bent on annihilating one another. ${ }^{19}$ ) The French Manager, who introduced the Chinese Conjuror, became a dancer encased in a huge cardboard caricature of Diaghilev, smoking a pipe the size of trombone, with a row of cut-out trees nonchalantly glued to the side, as if he were both a stroller and a perambulating landscape. The American Manager, who introduced the American Girl, became a dancer trying to move within a great cubist reconstruction of a skyscraper. The Manager who introduced the Acrobats was intended to be a dummy astride a pantomime horse; but, when the dummy kept falling off, the pantomime horse performed the role bareback, and became a general object of displeasure for audience and performers alike-the audience complained, understandably, that such cheap tricks could be seen elsewhere for far less money.

In Parade, Picasso reproduced theatrically how we would live if we could live inside a cubist painting. To some extent, the whole cubist revolution consists of the discovery that objects and the space around objects could be treated in a uniform manner: objects made up of facets inhabit a faceted space, as if there were no distinction between foreground and background, between solid bodies and air. Braque said that he tried to paint the "visual space" that "separates objects from each other"-"This in-between space [entre-deux] seems to me just as important as the objects themselves." 20 In "analytical" cubism, crumpled objects take shape amid a crumpled sky. Picasso himself suggested that his cubist paintings were like flattened-out sculptures, or like instructions for folding paper into a three-dimensional shape: the spectator should feel able to "cut up" the canvas and put it back together and "find oneself confronted with a sculpture." 21 A cubist drawing, then, is more like a set of instructions for folding a paper doll or a paper airplane than like a traditional

18Cocteau, Le Coq et l'Arlequin, 71.

19Cocteau was again the victim in the other most notable instance of collaborator annihilation: Stravinsky's insistence that Cocteau's libretto for Oedipus Rex be translated "backwards" into Latin was motivated in large measure by his desire to render Cocteau invisible in the final work.

20 In William Rubin, ed., Cézanne: The Late Work (New York: The Museum of Modern Art, 1977), $169,198$.

21 Douglas Cooper, The Cubist Epoch (London: Phaidon Press, 1970), 33. 
perspective drawing in which the parallel lines of objects in three-dimensional space are represented as toed-in lines receding to a single vanishing point.

And yet, it is a mistake to believe that cubist drawing is entirely liberated from the conventions of perspective drawing: Braque and Picasso simply insisted that these conventions must operate, not on the whole plane of the picture field, but on the individual facets exclusively. If you take a crosshatched trapezoid, suspend it against a black background, and display it through a peephole to anyone raised in the conventions of Western art, the spectator will describe it as a rectangle seen obliquely; but a spectator not raised in the conventions of Western art will describe it as what it is, a trapezoid. The facets of a cubist painting depend on the elementary (but not universal) apprehension that a square with slanty lines sticking out of its corners is a representation of a cube; without that understanding the picture is meaningless, but with that understanding the spectator can discover images that constitute themselves volumetrically in an amorphous space made up out of a vast heap of tiny individual spaces-for each facet occupies its own miniature continuum. For the cubist, the cube is an atom of space, susceptible to arbitrary recombination with other atoms of space. And this cubist multi-spatiality entails an altered physiology of perception: the spectator apprehends the drawing with fifty different eyes, projecting outward on stalks and curving around the object, the object seen full-face and three-quarter-face and profile all at the same time. Cubist art may seem somewhat static, passive, but only because the activity has been transferred from the (tranquilized) object depicted, to the (vehemently darting) gaze of the onlooker. To study a cubist picture is to become a lobster.

This peculiar intimacy of thing and atmosphere and eyeball makes Parade a disturbing spectacle. Picasso's backdrop shows buildings leaning outward at crazy angles over a proscenium arch, itself tilted; when the American Manager ambles out, he is a strange combination of a man and a building-an hommedécor in Cocteau's phrase-as if the stage set has popped itself out into three dimensions and started to dance. Furthermore, in the lower right of the backdrop, Picasso painted stippled silhouettes of figures wearing top hats, fashionable clothes-that is, the imaginary shadows of the audience itself. Instead of the normal three-plane theatrical model: (1) the audience, safe in its seats, contemplates (2) human actors, performing in front of (3) immobile scenery; Parade shatters all three planes into fragments, each of which is an odd jumble of decor, performer, and spectator. The French Manager, with trees growing from his back, is a personification of the whole theatrical environment, a stage-fragment moving through a puzzling space constituted by other stagefragments. The only proper conclusion to such a piece is a scandal, for the audience must surely involve itself in the dramatic action, even if only by throwing things at the performers.

Of course, the previous paragraph should have begun, This peculiar intimacy of thing and atmosphere and eyeball and ear: Satie's music, with its texture of varied or unvaried self-quotation, has a cubist rhythm as well. If the noteheads of the Chinese Conjuror's 1-4-3-7, 4-3-2, 4-3-3, 4-3-7 figure were connected, they would trace a zigzag line starting up in predictable directions 
from the stable 4-3 unit, like slant-lines proceeding from the corners of a square; and there are many places where extremely repetitive two-note bass ostinati seem to figure Satie's score with little rhombs. Darius Milhaud noted that the vocal line of Satie's Socrate "is of such absolute purity that, if, just for fun, one followed its ascending and descending, or even static, movement, the result would be a drawing incorporating the pure lines of ancient Greek masterpieces"; 22 but the connect-the-dots game, if played with Parade, seems to yield something far more up-to-date. In the Acrobats' scene-which Cocteau intended to represent manned flight and other sorts of technological progress-there is a foghorn-like organ pipe (rehearsal figure 39), above which appear two slow, strongly accented, up-down-up string figures: the first consists of scale degrees (in C major) 6-7-3, repeated twelve times; then, as the diapason shifts from 3 to 2 , the second figure appears, 7-flat-1-4, repeated four times; then the first figure and the first bass reappear, repeated eight times. In the Cubist context of Parade, these two figures seem to constitute a single acoustic object, carefully examined from two different points of view. The mere fact that the figures are repeated in groups of four gives a strong rectilinearity to this section. This music is not acrobatic, not lithe, not airy, but heavily incised, immobile: Satie may have felt that his true collaborator on Parade was Picasso, not Cocteau.

Satie paid little attention to the content of Parade, as Cocteau imagined it: the Chinese Conjuror's music is no more Oriental than the Acrobats' music (the Acrobats, for example, perform to pentatonic xylophones); the scenario of Parade did lead Satie to quote Irving Berlin's That Mysterious Rag for the American Girl (as Ornella Volta has noticed ${ }^{23}$ ), but the syncopated tune is oddly de-Americanized, bleached out, in the antiseptic context of Parade. Satie, however, paid close attention to the style of Parade, as Picasso imagined it; and the music can be heard as a kind of academic exercise for a Schola Cuborum. Some critics of Parade feel that Satie's music is no more cubist than any other piece of music devised according to a principle of pattern-unit construction; but I believe that the angled three-note figures so common in the score of Parade are metaphors for cubes as plausible as the individual facets of Picasso's drawing - facets which, as we have seen, are themselves only metaphors for cubes. The music tries to inscribe its status as an object through a number of unusual strategies.

In addition to this sound-spectacle derived from "analytical" cubist drawing - the reconstruction of the smooth continuous volumes of objects in the visible world with big jerky pixels-Parade also offers a sound-spectacle derived from "synthetic" cubist design, that is, the piecing-together of imaginary fields of reality through odd collages of ready-made objects, or of artful counterfeits of ready-made objects. Cocteau thought that this appropriation of "synthetic" cubism was far more important than such "analytical" artifacts as the American Manager's skyscraper costume:

22Notes to Vox CDX 5107, 9-10.

23See Rothschild, Picasso's "Parade", 89. 
Contrary to what the public imagines, [the Chinese Conjuror, the American Girl, and the two Acrobats] are more relevant to the cubist school than our managers are. The managers are prop-humans [hommes-décor], Picasso pictures that move, and their structure itself imposes a certain choreographic style. For the four main characters, it was a question of taking a collection of real gestures [gestes réels] and of metamorphosing them into dance, without losing their realistic force, as the modern painter is inspired by real objects to metamorphose them into pure painting, without, however, losing sight of the power of their volumes, their materials, their colors, and their shadows. ${ }^{24}$

Massine, and others involved in the dance aspects of Parade, gave Cocteau considerable credit for the choreography of the piece: Cocteau would model commonplace gestures, and Massine and the others would find ways of building a pantomime around those gestures. In this fashion, Parade translated into the formal and ceremonious world of ballet the gestural equivalent of slang: for example, there is a well-known photograph of Marie Chabelska in her nautical American school-girl costume, with flat, turned-out feet, with her legs bowed out in an innocent but extremely unladylike fashion, and with her forearms sticking forward, fingers curled and thumbs pointing right and left-a what-me-worry shrug with her whole body.

The subtitle of Parade is Ballet réaliste, and it is realistic not only in its visual gestures but in its sounds. Just as Cocteau hunted for odd moderne bits of body-deportment, Satie hunted for odd moderne noises-though, in the absence of a coherent scenario to connect the sound-effects with the gestures, the realism of the sound only reinforces the dissonance, the uncoordinatedness of the sound-world and the sight-world. Satie's score has cues for a typewriter, a pistol, a high siren, a low siren, a lottery wheel, and something called flaques sonores, sound-puddles, evidently made by dropping a cymbal on a hard floor; Cocteau also wanted Morse-code apparatus and a variety of other sounds: "The score of Parade ought to serve as the musical base for suggestive noises, such as sirens, typewriters, airplanes, dynamos, put there as what Georges Braque so justly calls 'facts' [faits]." 25 Just as Braque and Picasso glued real cards, or snippets of newsprint, or fragments of musical score, onto their cubist collages, so Satie created percussion parts, or a background of continuous indeterminately pitched sound, out of the technological innovations of the age. John Cage considered that the background sounds of a performance were part of the performance itself; Satie, on the other hand, invented the background sounds and scored them into the performance. For proper musique d'ameublement one needs to find talking furniture.

And yet, it is exactly at this level, where noises are glued onto Satie's orchestral score in the best Cubist fashion, that the essential unlikeness of Picasso and Satie becomes manifest. Picasso's collages are overwhelmingly

24Cocteau, Le Coq et l'Arlequin, 73. It should be noted that Cocteau is commending an aspect of Parade for which he, not Picasso, could be credited.

25Ibid., 37. 
purposeful. Francis Frascina has shown, ${ }^{26}$ in great detail, how, in Nature morte 'Au Bon Marche' (1913), Picasso isolates, through careful snipping, the syllables trou (hole) and ici (here) from newspaper headlines, in order to point out, or heighten, the sexual provocativeness of a drawing of a woman cut from a department-store advertisement: Picasso has converted, crumpled up, the Bon Marché into a market that sells, not women's clothes, but women. Picasso clearly intended Parade to be a nature vivante equivalent to this sort of collage: the male Acrobat's costume has a huge spiral whorl right over his groin, and a number of other design elements can also be derived from drawings of penises that Cocteau and Picasso swapped while visiting Italy together in 1917.27 The collage mode that Picasso best understood was the sex rebus, though he sometimes experimented with other sorts of integrating schemes as well.

But what sort of integrating principle can be found in Satie's noise-collage? To put the question another way, what sort of noise might be inappropriate? A moo or a tweet would be inappropriate, since all the noises are mechanical in character; but it is not easy to think of any other restriction, since the noises seem chosen to impart a sense of the greatest possible sonic variety. Furthermore, with the exceptions of the revolver shots and the pseudo-foghorn, the noises simply perch precariously on top of the orchestral score: Satie was no Varèse, and he went to no effort to integrate them timbrally or rhythmically with the regular instruments. Just as the American Girl pantomimes a series of actions so diverse that they seem purely random, so Satie includes noises by chance. Parade preceded most of the Dada experiments with random construction, such as Tzara's generation of poems by tossing separate word-scraps in a hat; and certainly Satie had no particular interest in aggressive proclamations of disorder. Satie's unobtrusive disorder-disorder that comes into play simply because the artist feels that no other choice is possible-has a distinct postmodernist savor.

Satie was not the first composer to experiment with noise. The Futurist Luigi Russolo-more a painter than a musician-devised a series of intonarumori, noise-intoners, all enclosed in black boxes, as if a cubist's cubes had been taught to speak. These included Ululatori, Rombatori, Crepitatori, Gorgogliatori, and Sibilatori (howlers, rumblers, cracklers, gurglers, hissers), and Russolo devised concert-pieces for them, such as the 1913 Veglio di una città (Awakening of a city), the score to which is a fine piece of Futurist graphic, with its normal bars, clefs, time signatures, and staves, all decorated with thick black lines, holding steadily horizontal, or ascending up and down in slow glides, or proceeding in fast jerks from one flat line to the next-a visual anticipation of the later Mondrian.28

It is difficult to know what the intonarumori sounded like. The instruments themselves seem no longer to exist; in 1977 Mario Abate and Pietro Verardo reconstructed them and recorded Veglio di una città-which seems a dis-

26See Charles Harrison, et al., Primitivism Cubism Abstractionism: The Early Twentieth Century (New Haven: Yale University Press, 1993), 88.

27See Rothschild, Picasso's "Parade", 62, 68.

28See Caroline Tisdall and Angelo Bozzolla, Futurism (London: Thames and Hudson, 1977), 117. 
appointingly lackadaisical succession of borborygms and distant airplanes. Still more disappointing is the one surviving recording of the original intonarumori, ${ }^{29}$ unfortunately used as underlay to a conventional Corale \& Serenata, composed by Russolo's brother Antonio and scored for normal instruments: to hear it is to hear insipid tunes faintly disrupted by various growls, like a radio broadcast with low-pitched electric interference. Still, the premise of Parade is there, in embryo, in this old Futurist record: unpitched contrivances that interject into the domain of art music a collection of sub-artistic noises, a new repertoire in acoustic semantics. Here music tries to cope with the random urgencies of urban sirens, with the information overload of a frantic typewriter and a Morse-code apparatus, signaling in the void from no one in particular to no one in particular. Parade brought into the theatre a simulation of the general background static of the twentieth century.

Indeed what interested Satie was the static, not the noises per se. Baudrillard has imagined postmodern man as

an astronaut in his capsule ... at the controls of a micro-satellite, in orbit, living no longer as an actor or dramaturge but as a terminal of multiple networks.... this electronic "encephalization" and miniaturization of circuits and energy, this transistorization of the environment, relegates to total uselessness, desuetude and almost obscenity all that used to fill the scene of our lives.... The real itself appears as a large useless body. ${ }^{30}$

In Parade, the typewriter sounds, the whole apparatus of sonorous flak, seem to represent something obscene, the clangor of reality's large useless body, intruding faintly onto the encephalized music-even as the music ignores the noise, swallows the noise, as if the noise had never been. Satie's music, with its extreme disengagement from appetite, from expression, is as close to space-capsule art as anything the early twentieth century can provide; in Parade we hear a strange sound, a pre-audition of the Postmodern consuming the Modern, rendering its whole artillery of technological potencies absurd.

\begin{abstract}
If postmodernism can be considered ahistorically, as a stylistic category operative at any time and in any place, then there are many older works that suddenly seem to speak strongly to our present age. This paper argues the case for taking Erik Satie as a postmodernist: his music is marked by bricolage (the Edriophthalma movement from Embryons desséchés, 1913, borrows a theme, according to the score, "from a celebrated mazurka by Schubert"); by polystylism (the cabaret songs written for Vincent Hyspa, or Parade with its
\end{abstract}

29Listen to Societi Nazionale del Grammofono R6919/20, reissued on Sub Rosa SUBCD 01219-an extraordinary anthology of Futurist sound-texts.

30 Jean Baudrillard, "The Ecstasy of Communication," in Hal Foster, The Anti-Aesthetic: Essays on Postmodern Culture (New York: The New Press, 1983), 128-29. 
quotation from Irving Berlin); and by materialism of the signifier (what Satie calls furniture music).

\section{Résumé}

Si le postmodernisme peut se concevoir de façon a-historique comme une catégorie stylistique clé, quel que soit le moment ou le lieu, beaucoup d'œuvres plus anciennes prennent tout à coup, à l'époque actuelle, une certaine importance. Cet essai illustre ce point de vue en qualifiant Erik Satie de postmoderniste. En effet, sa musique est marquée par le bricolage (le mouvement "Edriophthalma » des Embryons desséchés de 1913 emprunte, selon la partition, un thème tiré "d'une célèbre mazurka de Schubert »), par la multiplicité des styles (les chansons de cabaret écrites pour Vincent Hyspa, ou encore Parade et ses citations d'Irving Berlin) et par le matérialisme du signifiant (ce que Satie nomme la musique d'ameublement). 